\title{
ВЛИЯНИЕ СРОКА И СПОСОБА УБОРКИ НА УРОЖАЙНОСТЬ И КАЧЕСТВО ЗЕРНА ОЗИМЫХ КУЛЬТУР В ОДНОВИДОВЫХ И БИНАРНЫХ ПОСЕВАХ
}

\author{
A.A. Arefin, R.B. Nurlygayanov
}

\section{THE INFLUENCE OF THE TERM AND WAY OF HARVESTING ON THE YIELD AND THE QUALITY OF WINTER CROPS IN SINGLE-SPECIES AND BINARY CROPS}

Арефин Алексей Алексеевич - директор ООО «Михайловское», Кемеровская обл., Прокопьевский р-н, с. Михайловка, соискатель каф. агрономии, селекции и семеноводства Кузбасской государственной сельскохозяйственной академии, г. Кемерово. E-mail: razit2007@mail.ru

Нурльгаянов Разит Баязитович - д-р с.-х. наук, проф. каф. почвоведения, агрохимии и точного земледелия Башкирского государственного аграрного университета, г. Уфа, вед. науч. сотр. отдела полевого кормопроизводства Сибирского ФНЦ агробиотехнологий РАН, Новосибирская обл., Новосибирский р-н, п. Краснообск. E-mail: razit2007@mail.ru

Цель исследований - изучить зависимость формирования урожайности и качества зерна озимой вики с озимой рожью от способа и срока уборки. Исследование проводилось на опьтном поле ООО «Михайловское» Прокопьевского района Кемеровской области (лесостепная зона Западной Сибири) в 2015-2017 г2. Объектом исследования были выбраны озимая вика сорта Фортуна селекции Алтайского НИИСХ и озимая рожь сорта Тетра короткая селекции СибНИИРС и Института цитологии и генетики СО РАН. Схема двухфакторного опыта: 1) однофразная уборка при влажности зерна ржи $20 \%$; 2) однофазная уборка при влажности зерна ржи $14 \%$; 3) двухфазная уборка при влажности зерна ржи 20 \%; 4) двухфазная уборка при влажности зерна ржи $14 \%$. Площадь делянок в опытах - 200 м², 3-кратная повторность. Расположение вариантов - систематическое. Уборка растений на зерно проводили комбайном New Holland; скашивание валков - самоходной жаткой MacDon при влажности зерна 25 \%. При расчете урожайности зерна влажность была до-
Arefin Alexey Alexeevich - Director, JSC "Mikhaylovskoe", Kemerovo Region, Prokopyevsk District, V. Mikhaylovka, Applicant, Chair of Agronomy, Selection and Seed Farming, Kuzbass State Agricultural Academy, Kemerovo.

E-mail: razit2007@mail.ru

Nurlygayanov Razit Bayazitovich - Dr. Agr. Sci., Prof., Chair of Soil Science, Agrochemistry and Exact Agriculture, Bashkir State Agrarian University, Ufa, Leading Staff Scientist, Department of Field Forage Production, Siberian FRC of Agrobiotechnologies of RAS, Novosibirsk Region, Novosibirsk District, S. Krasnoobsk.

E-mail: razit2007@mail.ru

ведена до стандартной - 14 \%. Сроки и способы уборки повышают урожайность зерна исследуемых культур: озимой ржи до 0,28 m/2a, озимой вики - до 0,50 и зерносмеси до 0,31 m/2а. Двухфазная уборка при влажности зерна озимой ржи 14 \% повышает урожайность озимой ржи на 0,18 m/2a, озимой вики - на 0,39 m/2а, зерносмеси - на 0,30 m/2а. Доля зерна озимой ржи в зерносмеси сократилось от 71 до 59 \%. Соответственно повысилась доля зерна озимой вики - от 29 до 41 \%. При двухфразной уборке доля зерна в смеси сократилась на $3 \%$, что объясняется более интенсивным оттоком питательных веществ в зерно озимой вики в результате прекращения роста и развития растений. Содержание белка в зерне (основной показатель качества) от срока и способа уборки увеличивалось по всем вариантам исследования: озимой ржи - на 1,2 \%; озимой вики - на 2,20; зерносмеси - на 2,9\%. Соответственно повысился сбор белка за единицу площади: озимой ржи - на 0,06 m/2a, озимой вики - на 0,16 и зерносмеси - на 0,12 m/2а. 
Ключевые слова: озимая рожь, озимая вика, урожайность, содержание белка, срок и способы уборки, влажность зерна.

The research objective was to study the formation of productivity and quality of winter vetch grain with winter rye from the way and the term of harvesting. The research was conducted on experimental field of JSC "Mikhaylovskoe" of Prokopyevsk district, Kemerovo Region (forest-steppe zone of Western Siberia) in 2015-2017. The variety Fortuna of Altai RDIA selection and winter rye of the variety of Tetr short of SIBNIIRS and Institute of Cytology and Genetics SB RAS selection were chosen as the objects of the research of winter vetch. The scheme of two-factorial experiment: 1) single-phase harvesting at humidity of grain of a rye of $20 \%$; 2) single-phase harvesting at the humidity of grain of rye of $14 \%$; 3) two-phase harvesting at the humidity of grain of the rye of $20 \%$; 4) two-phase harvesting at the humidity of grain of a rye of $14 \%$. The area of allotments in the experiments was 200 sq.m with 3-fold frequency. The arrangement of options was systematic. Harvesting of plants on grain was carried out with the help of New Holland combine; bevelling of rolls - with selfpropelled harvester of MacDon at the humidity of grain of $25 \%$. At calculation of productivity of grain the humidity was brought to the standard - $14 \%$. The terms and ways of harvesting increase the productivity of grain of studied cultures: winter rye to $0.28 \mathrm{t} /$ hectare, winter vetch -0.50 and grain mix - 0.31 thectare. Two-phase harvesting at the humidity of grain of winter rye of $14 \%$ increases the productivity of winter rye by $0.18 \mathrm{t} /$ hectare, winter vetch - on 0.39 t/hectare, grain mix - on 0.30 thectare. The share of grain of winter rye in grain mix was reduced from 71 to $59 \%$. The share of grain of winter vetch rose, respectively from 29 to $41 \%$. At two-phase harvesting the grain share in mix was reduced by $3 \%$ that was explained by more intensive outflow of nutrients in winter vetch grain as a result of the termination of growth and development of plants. Grain protein content (the main indicator of the quality) from term and the way of harvesting increased by all options of research: winter rye - for $1.2 \%$; winter vetch - on 2.20; grain mix - for $2.9 \%$. The charge protein for unit of area increased, respectively: winter rye - on 0.06 thectare, winter vetch - on 0.16 and grain mix - on 0.12 thectare.
Keywords: winter rye, winter vetch, yield, protein content, term and ways of harvesting, grain moisture.

Введение. Полевое кормопроизводство выполняет многофункциональную деятельность гарантированное обеспечение животноводства высококачественными кормами на планируемую продуктивность скота, создание устойчивого фитосанитарного состояния и повышение плодородия почвы за счет плодосмена, фиксации биологического азота при возделывании бобовых культур и др. Научно обоснованное сочетание полевого кормопроизводства с естественными кормовыми угодьями в производстве кормов позволяет трансформацию элементов минерального питания на пашню [1, 2]. Особое место в полевом кормопроизводстве занимают озимые культуры в смеси с единственным озимым видом зернобобовых культур - озимой викой. Несмотря на высококачественный корм, смесь озимых зерновых культур с озимой викой в хозяйствах возделывается в небольших объемах. Это относится и к регионам Западной Сибири $[3,4]$.

Ограниченность периода заготовки кормов в условиях Западной Сибири требует изыскать различные источники сырья из однолетних и многолетних трав с учетом их биологических особенностей и продуктивности. Среди однолетних трав ведущее место принадлежит озимым полевым культурам, обеспечивающим зеленую массу в ранние периоды весны, когда наблюдается дефицит кормов и низкая продуктивность естественных пастбищ и культурных многолетних трав. За счет озимых культур можно приступить к заготовке кормов на стойловый период в ранние сроки.

Озимые зерновые злаковые культуры созревают равномерно, озимая вика, напротив, - неравномерно и растянуто, т. е. одновременно на растениях могут быть вполне созревшие бобы со зрелым зерном и зеленые - с недозревшими семенами. Не исключено наличие бутонов с цветками на верхней части стебля, тогда как у зернового компонента к этому времени в целом завершается формирование зерна в колосе. Биологические особенности озимой вики сильно отличаются от особенностей злаковых компонентов. Цветение растений озимой вики начи- 
нается с нижней кисти и поднимается вверх по растению, и соответственно идет формирование бобов и семян в них [5]. Нижние цветки зацветают и оплодотворяются на 5-6 дней раньше, чем цветки среднего, и на 10-15 дней раньше, чем цветки верхнего яруса. В результате происходит неравномерное созревание семян [6].

Поэтому сроки и способы уборки семян озимой вики имеют весьма определяющее значение для получения полноценного зерна и семенного материала. Созревшее зерно озимой вики накапливает наибольшее количество белка, повышаются посевные качества семян. Как правило, разнокачественный семенной материал обеспечивает неравномерные всходы и густоту растений на посевах, повышается вероятность гибели растений в период перезимовки. Низкая эфффективность семеноводства озимой вики (всхожесть семян) обусловлена биологическими особенностями развития культуры: непрекращающимися ростом и развитием растений, растянутостью периода созревания бобов и осыпанием семян из-за растрескивания бобов при неустойчивой температуре и влажности воздуха. При установлении сроков и способов уборки озимой вики необходимо учитывать фразу спелости опорной (злаковой) культуры. По данным ряда исследований установлено, что из-за неправильного подбора вида опорных культур и их соотношения с викой, приводящих к сильному полеганию, несоблюдения сроков и технологии уборки фактические сборы семян не превышают 25-30 \% от сфрормированного биологического урожая [7].

Для бобовых культур характерно развитие плодов в два этапа: первый - формирование створок боба и второй - развитие семян в бобе [8]. Это не исключение и для культуры озимой вики. Первый этап может продлиться от полутора до двух с половиной недель, начинается после увядания цветка с появлением зачаточного боба. К концу первого этапа за счет интенсивного поступления пластических веществ влажность боба и семян внутри снижается до 8075 \%. Плод полностью завершает свое формирование, набирает наибольший размер, внутри окончательное количество семян. Во втором этапе продолжается формирование и налив семян. Этап делится на три фазы: углеводное со- стояние, белковая или уборочная спелость и полная хозяйственная спелость зерна [9]. Этапы созревания семян различны как на одном растении, так и в целом по посеву. В результате формируются семена с различными качественными показателями. Данный недостаток до определенной степени можно регулировать за счет правильного выбора способа и срока уборки зерна озимой вики.

Цель исследований: изучить условия формирования урожайности и качества зерна озимой вики с озимой рожью в зависимости от сроков и способов уборки.

Условия и методика исследований. Исследования проводились на опытном поле ООО «Михайловское» Прокопьевского района Кемеровской области (лесостепная зона Западной Сибири) в 2015-2017 гг.

Объектом исследований были выбраны озимая вика сорта Фортуна селекции Алтайского НИИСХ и озимая рожь сорта Тетра короткая селекции СибНИИРС и Института цитологии и генетики СО РАН.

Схема полевого опыта: 1) однофразная уборка при влажности зерна озимой ржи $20 \%$; 2) однофразная уборка при влажности зерна озимой ржи $14 \%$; 3) двухфазная уборка при влажности зерна озимой ржи $20 \%$; 4) двухфазная уборка при влажности озимой зерна ржи $14 \%$. Площадь делянок в опытах - 200 м², 3-кратная повторность. Расположение вариантов - систематическое. Уборка растений на зерно проводили комбайном New Holland; скашивание валков - самоходной жаткой MacDon при влажности зерна $25 \%$. При расчете урожайности зерна озимой ржи, озимой вики и зерносмеси влажность была доведена до стандартной - $14 \%$.

Результаты исследований и их обсуждение. Качество получаемых при уборке семян сельскохозяйственных растений зависит от степени развития зародыша и запаса питательных веществ в форме эндосперма, формирование которых идет за счет оттока синтезированных органических веществ из вегетативных органов (листьев и стебля). Чем мощнее развит и дифференцирован зародыш и больше накоплен запас питательных веществ в семени, тем интенсивнее дальнейший рост и развитие растений в последующем поколении. 
Семена озимой вики в процессе своего развития от момента формирования до полного созревания проходят ряд фраз, где происходит качественное изменение биохимических и морфологических свойств. Процесс развития семян на растении сопровождается изменениями и стабилизацией показателей качества: накопление в достаточном количестве сухого вещества, повышение энергии прорастания и всхожести самих семян.

На практике, как правило, уборку зернобобовых, в частности смеси озимой вики с озимой рожью, проводят двумя способами - прямым комбайнированием и раздельно - скашиванием травостоя в валки с последующей подборкой валков. Второй способ при уборке культурных растений, в частности бобовых культур, повышает себестоимость уборочных работ и семян, но это остается основным агротехническим приемом. Так как бобовые культурные растения, в частности озимая вика, полностью полегают к земле и прямой обмолот трудно достижим, то двухфазная уборка является вынужденной мерой. Это относится к чистым посевам гороха и вики. Срок скашивания при раздельной уборке в фазе побурения 50-60 \% бобов. Подбор валков проводят по мере высушивания скошенной массы и при влажности семян 16$18 \%$. При более низкой влажности происходит сильное дробление семян, а при влажности свыше $20 \%$ увеличивается травмируемость [10].

В одновидовых (чистых) посевах озимая вика полегает, особенно при достаточном уровне влагообеспеченности, что в сильной степени нарушает процесс семяобразования и усложняет проведение уборки зерна. Длинный тонкий стебель озимой вики к концу завершения вегетации полностью полегает на землю, становится трудноскашиваемым в валки, практически полностью не пригодным к прямой уборке. Поэтому производство семян озимой вики осуществляется в смешанных посевах в смеси с озимыми злаковыми. На таких посевах озимые злаковые выполняют роль опорной поддерживающей культуры. Такое сочетание считается более практическим агротехническим приемом. Стебель озимой вики тонкий и длинный, имеет слабую прочность. По нашим наблюдениям, на посевах смеси озимой вики с озимой пшеницей в ООО «Михайловское» в 2012 г., в очень за- сушливом сезоне в истории Кузбасса за последние сто лет, длина растений бобового компонента достигла 2 м 30 см.

Сроки и способы уборки озимых культур показали изменчивость формирования урожайности зерна за единицу площади. Как было отмечено выше, сроки уборки смеси озимой вики с озимой рожью определяются созреванием злакового компонента. В это время бобовый компонент (озимая вика) продолжает вегетацию, хотя в нижних частях растений бобы и семена в бобах созрели. Вариант «однофразная уборка при влажности зерна озимой ржи 20 \%» обеспечил наименьшую урожайность зерна в сравнении с однофазной уборкой при влажности зерна $14 \%$. В данном варианте продуктивность смеси была выше, чем на одновидовых посевах на озимой ржи $(+0,18$ т/га) и по озимой вике $(+0,131 \mathrm{т} / г a)$.

Во втором варианте - «однофразная уборка при влажности зерна ржи $14 \%$ урожайность зерна повысилась по всем вариантам опыта и была выше, чем по первому варианту опыта. Урожайность зерна озимой ржи на чистых посевах повысилась на 4,92 \%, озимой вики - на 10,52 \%. Урожайность зерносмеси повысилась на 0,11 т/га, или на $5 \%$. В смеси доля озимой ржи снизилась на 5 \%. При снижении влажности зерна ржи продолжается отток питательных веществ из вегетативных частей с увеличением массы семян в колосе. На растениях озимой вики повышение урожайности зерна происходит также за счет увеличения массы семян.

На третьем варианте опыта урожайность зерна как в одновидовых, так и в бинарном посеве повысилась в сравнении с однофазной уборкой. Чистые посевы озимой ржи обеспечили прибавку урожайности на +0,25 т/га (+12,3 \%) в сравнении с прямой уборкой. Данный показатель у озимой вики составил +0,38 т/га (+12,5 \%), у зерносмеси $+2,3$ т/га $(+10,4 \%)$.

На четвертом варианте опыта - «двухфазная уборка при влажности зерна ржи 14 \%» отмечалось некоторое повышение урожайности зерна исследуемых культур и их смеси. Урожайность зерна озимой ржи повысилось на 0,03 т/га $(+1,3 \%)$, озимой вики - на 0,03 т/га $(+1,0 \%)$, зерносмеси - 0,8 т/га (+3,3 \%). Это, как мы полагаем, стало результатом использования биологического азота, синтезируемого озимой викой и используемого растениями озимой ржи, как бы- 
вает в смешанных посевах злаковых и бобовых культур. Однако данные прибавки урожайности зерна во все годы исследований несущественные (НСР 05 поставил от 0,009-0,17).

Способы и сроки уборки озимых культур в одновидовых и бинарных посевах повысили урожайность зерна озимой ржи на 0,28 т/га $(+13,8 \%)$, озимой вики - на 0,50 т/га $(+26,3 \%)$, зерносмеси - на 0,31 т/га (+14,0\%). При двухфазной уборке (скашивание растений на валки при влажности зерна растений озимой ржи $25 \%)$ происходит разрыв питания растений, т. е. прекращение поступления элементов минерального питания из корневой системы. После скашивания начинается отток питательных веществ из стебля и листьев на генеративный орган (зерно, семя). При нахождении растений на корню в конце онтогенеза злаковый компонент завершает корневое питание (поступление элементов минерального питания из почвы) с продолжением оттока питательных веществ из стебля и листьев. По этой причине повышается урожайность зерна озимой ржи при двухфазной уборке. Для культуры озимой вики онтогенез не завершается, процесс роста и развития растений продолжается. При двухфазной уборке прекращается полное поступление элементов минерального питания из корневой системы и начинается отток питательных веществ в семена. При обмолоте валков озимой вики и смеси при влажности зерна озимой ржи $20 \%$ отток питательных веществ озимой вики не завершается, свидетельством этого является урожайность зерна в чистом виде на уровне 2,37 т/га, в смеси 1,51 т/га. При дальнейшем нахождении растений на валках приток элементов питания в семена вики продолжается, тем самым повышается урожайность зерна как в одновидовых, так и в бинарных посевах. При обмолоте озимой вики и смеси при влажности зерна озимой ржи $14 \%$ урожайность чистых посевов повысилась, о чем было отмечено выше.

От способа и срока уборки изменяется качественный состав зерносмеси. Если первоначально доля озимой ржи в зерносмеси выше в сравнении с озимой викой, то в последующем данный показатель снижается в пользу озимой вики.

Доля зерна озимой ржи в зерносмеси с $71 \%$ в первом варианте снизилась до 59 \% в четвертом. Соответственно повышалась доля зерна озимой вики. Это объяснимо наличием питательных веществ в стебле и листьях озимой вики, приток которых на генеративный орган зерно идет интенсивно после скашивания, растения прекращают рост и развитие.

Таким образом, наибольшая урожайность зерносмеси озимой ржи с озимой викой формируется в двухфазной уборке при подборе валков $14 \%$ влажности зерна злакового компонента.

Сроки и способы уборки исследуемых культур не только повышали продуктивность растений, но и качество зерна. Однофазная уборка озимой ржи при влажности зерна $20 \%$ обеспечила сбор белка 0,35 т/га. Содержание белка в зерне составило 12,2 \%. В данной фазе белковость зерна озимой вики составила 21,20\%, выход белка - 0,40 т/га. Сбор белка с 1 га зерносмеси составил 0,34 т/га, что больше от показателя чистого посева озимой ржи и меньше от озимой вики за единицу площади пашни. Во втором варианте опыта (однофазная уборка при влажности зерна ржи $14 \%$ ) белковость зерна в одновидовых и бинарном посевах повышается за счет притока питательных веществ из вегетативной части в генеративную. Было отмечено одинаковое количество накопления доли белка в зерносмеси зерном озимой ржи. Несмотря на то, что повышается белковость зерна ржи, снижается его доля в зерновой массе смеси и соответственно ее выход на единицу площади.

Таблица 1

\section{Урожайность озимых культур в одновидовых и бинарных посевах при разных сроках и способах уборки (среднее за 2015-2017 гг.), т/га}

\begin{tabular}{|c|c|c|c|c|c|c|c|}
\hline \multirow{2}{*}{$\begin{array}{c}\text { Срок и способ } \\
\text { уборки }\end{array}$} & \multirow{2}{*}{$\begin{array}{c}\text { Озимая } \\
\text { рожь }\end{array}$} & \multirow{2}{*}{$\begin{array}{c}\text { Озимая } \\
\text { вика }\end{array}$} & \multicolumn{5}{|c|}{ Омесь озимой вики с озимой рожью } \\
\cline { 5 - 8 } & & & Общая & \multicolumn{2}{|c|}{ Озимая рожь } & \multicolumn{3}{|c|}{ Озимая вика } \\
\hline 1 & 2 & 3 & 4 & 5 & 6 & 7 & 8 \\
\hline $\begin{array}{l}1 . \text { Односразная } \\
\text { уборка при влаж- } \\
\text { ности 20 \% ржи }\end{array}$ & 2,03 & 1,90 & 2,21 & 71,00 & 1,57 & 29,00 & 0,64 \\
\hline
\end{tabular}




\begin{tabular}{|l|c|c|c|c|c|c|c|}
\hline \multicolumn{1}{|c|}{ 1 } & 2 & 3 & 4 & 5 & 6 & 7 & 8 \\
\hline $\begin{array}{l}\text { 2. Однофазная } \\
\text { уборка при } \\
\text { влажности 14 \% } \\
\text { ржи }\end{array}$ & 2,13 & 2,10 & 2,32 & 66,00 & 1,53 & 34,00 & 0,79 \\
\hline $\begin{array}{l}\text { 3. Двухфазная } \\
\text { уборка при } \\
\text { влажности 20 \% }\end{array}$ & 2,28 & 2,37 & 2,44 & 62,00 & 1,51 & 38,00 & 0,93 \\
\hline $\begin{array}{l}\text { 4. Двухфазная } \\
\text { уборка при } \\
\text { влажности 14 \% }\end{array}$ & 2,31 & 2,40 & 2,52 & 59,00 & 1,49 & 41,00 & 1,03 \\
\hline
\end{tabular}

При двухфазном способе уборки во всех вариантах было отмечено повышение содержания белка в зерне и зерносмеси. При косовице прекращается приток воды и элементов минерального питания из корневой системы и соответственно останавливается процесс фотосинтеза. Начинается интенсивный отток питательных веществ в колос озимой ржи и к бобам озимой вики.

В целом по вариантам опыта белковость зерна озимой ржи повысилась от 12,2 до 13,4 \%. Данный показатель зерна озимой вики составил от 21,20 до 23,40 \% соответственно. Сбор белка в зерносмеси повысился от 0,34 до 0,46 т/га, белковость повысилась с 15,4 до 18,3 \%.

Таблица 2

\section{Влияние сроков и способов уборки озимых культур в одновидовых и бинарных посевах на качество зерна (среднее за 2015-2017 гг.)}

\begin{tabular}{|c|c|c|c|c|c|c|c|c|c|c|}
\hline \multirow{3}{*}{$\begin{array}{c}\text { Срок и способ } \\
\text { уборки }\end{array}$} & \multirow{2}{*}{\multicolumn{2}{|c|}{$\begin{array}{c}\text { Озимая } \\
\text { рожь }\end{array}$}} & \multirow{2}{*}{\multicolumn{2}{|c|}{$\begin{array}{c}\text { Озимая } \\
\text { вика }\end{array}$}} & \multicolumn{6}{|c|}{ Зерносмесь } \\
\hline & & & & & \multicolumn{2}{|c|}{ Озимая рожь } & \multicolumn{2}{|c|}{ Озимая вика } & \multicolumn{2}{|c|}{ Общая } \\
\hline & $\%$ & $\begin{array}{c}\text { c } 1 \text { га, } \\
\text { T }\end{array}$ & $\%$ & $\begin{array}{c}\text { c } 1 \text { га, } \\
\text { T }\end{array}$ & $\%$ & $\begin{array}{c}\text { c } 1 \text { га, } \\
\text { T }\end{array}$ & $\%$ & $\begin{array}{c}\text { c } 1 \text { га, } \\
\text { T }\end{array}$ & $\%$ & $\begin{array}{c}\text { c } 1 \text { га, } \\
\text { T }\end{array}$ \\
\hline $\begin{array}{l}\text { Однофразная } \\
\text { уборка при } \\
\text { влажности } \\
\text { зерна ржи } 20 \text { \% }\end{array}$ & 12,2 & 0,25 & 21,20 & 0,40 & 12,6 & 0,20 & 22,00 & 0,14 & 15,4 & 0,34 \\
\hline $\begin{array}{l}\text { Однофразная } \\
\text { уборка при } \\
\text { влажности } \\
\text { зерна ржи } 14 \text { \% }\end{array}$ & 12,8 & 0,27 & 21,90 & 0,46 & 13,2 & 0,20 & 22,8 & 0,18 & 16,4 & 0,38 \\
\hline $\begin{array}{l}\text { Двухфразная } \\
\text { уборка при } \\
\text { влажности } \\
\text { зерна ржи } 20 \text { \% }\end{array}$ & 13,1 & 0,30 & 22,50 & 0,53 & 13,5 & 0,21 & 23,9 & 0,22 & 17,6 & 0,43 \\
\hline $\begin{array}{l}\text { Двухфазная } \\
\text { уборка через } \\
\text { при влажности } \\
\text { зерна } 14 \text { \% }\end{array}$ & 13,4 & 0,31 & 23,40 & 0,56 & 13,90 & 0,21 & 24,30 & 0,25 & 18,3 & 0,46 \\
\hline
\end{tabular}

Как показали расчеты по экономической эффективности сроков и способов уборки ози- мых культур в одинарных и бинарных посевах, рентабельность производства повышается по 
мере повышения продуктивности растений. Рентабельность двухфазного обмолота зерна озимой ржи при влажности $20 \%$ составила 90,8 \%. Это на 11,6 \% выше в сравнении с прямым комбайнированием. Данный показатель озимой вики составил 33,8 \%, по зерносмеси 4,9\%. При уборке 14 \% влажности зерна озимой ржи рентабельность повышается на 8,1 \% при двухфазной уборке злака, на $26 \%$ бобовой культуры и 5,7 \% зерносмеси.

Следует отметить, современные сельскохозяйственные машины отличаются высокой производительностью и существенно снижают себестоимость уборочных работ. Это относится и к самоходным косилкам. Как показали наши расчеты, затраты на косовицу высокопроизводительных самоходных косилок не уступают затратам послеуборочной обработки и сушки зерна при однофазной уборке. По вариантам опыта рентабельность производства зерна озимой ржи повысилась на 12,9\%; озимой вики на 35,7 ; зерносмеси - на 19,9\%. Сроки и способы уборки оказали наибольшее повышение рентабельности озимой вики. Это связано с повышением урожайности зерна озимой вики за счет его дозревания при двухфазной уборке путем прекращения корневого питания и оттока питательных веществ в семя.

\section{Выводы}

1. Сроки и способы уборки повышают урожайность зерна исследуемых культур: озимой ржи - до 0,28 т/га, озимой вики - до 0,50 т/га и зерносмеси - до 0,31 т/га. В зависимости от сроков и способов уборки доля зерна озимой ржи в зерносмеси сократилось от 71 до 59 \% с повышением доли зерна озимой вики соответственно от 29 до $41 \%$.

2. Содержание белка в зерне (основной показатель качества) от сроков и способов уборки увеличивалось у озимой ржи на 1,2 \%; озимой вики - на 2,20; зерносмеси - на 2,9 \%. Сбор белка за единицу площади у озимой ржи повысился на 0,06 т/га, озимой вики - на 0,16 и смеси 0,12 т/га.

3. Сроки и способы уборки повысили рентабельность производства зерна озимой ржи на $12,9 \%$; озимой вики - на 35,$7 ;$ зерносмеси - на $19,9 \%$.
Рекомендации производству. В условиях лесостепи Западной Сибири для получения высококачественного зерна озимой вики в бинарных посевах с озимой рожью уборку необходимо проводить двухфазно подбором валков при 14 \% влажности зерна ржи.

\section{Литература}

1. Банкрутенко А.В., Юдина Е.В. Повышение эффективности полевого кормопроизводства в подтайге Омской области // Вестник КрасГАУ. 2018. № 4. С. 26-30.

2. Байкалова Л.П., Едимечев Ю.Ф., Машанов А.И. Оценка урожайности культурных пастбищ в условиях Красноярского края // Вестник КрасГАУ. 2019. № 8. С. 52-58.

3. Арефин А.А. Влияние элементов технологии возделывания на продуктивность озимой вики с озимой рожью // Вестник КрасГАУ. 2020. № 1. С. 159-167.

4. Нурльгаянов Р.Б., Арефин А.А., Филимонов А.Л. Мохнатая вика поможет // Территория Агро. 2015. № 6. С. 22-24.

5. Репьев С.И., Станкеевич А.К., Леонкене Л.В. Культурная флора. Т. 4. Ч. 2. Вика. СПб: Изд-во ВИР, 1999. 492 с.

6. Козьмина Н. Биологические основы хранения семян // Зернобобовые культуры. 1963. № 1. C. 28-30.

7. Парахин Н.В., Золотарев В.Н., Лаханов А.П. и др. Вика мохнатая (Vicia villosa Roth.) в кормопроизводстве России. Орел: Изд-во ОрелГАУ, 2010.508 c.

8. Лукина Е.А., Федотов В.А., Кадыров С.В. и др. Семеноведение и семенной конторль: учебник. Воронеж: Издат-Черноземье, 2019. 332 c.

9. Коренев Г.В., Сафронов В.Е. Биологические периоды во время семяобразования и созревания гороха // Сельскохозяйственная биология. 1982. Т. 7, № 5. С. 661-665.

10. Золотарев В.Н., Новоселов Ю.К., Рудоман В.В. и др. Рекомендации по возделыванию и использованию вики мохнатой (озимой) на корм и семена. М., 2007. 45 с. 


\section{Literatura}

1. Bankrutenko A.V., Judina E.V. Povyshenie jeffektivnosti polevogo kormoproizvodstva $\mathrm{V}$ podtajge Omskoj oblasti // Vestnik KrasGAU. 2018. № 4. S. 26-30.

2. Bajkalova L.P., Edimechev Ju.F., Mashanov A.I. Ocenka urozhajnosti kul'turnyh pastbishh v uslovijah Krasnojarskogo kraja /I Vestnik KrasGAU. 2019. № 8. S. 52-58.

3. Arefin A.A. Vlijanie jelementov tehnologii vozdelyvanija na produktivnost' ozimoj viki s ozimoj rozh'ju // Vestnik KrasGAU. 2020. № 1. S. 159-167.

4. Nurlygajanov R.B., Arefin A.A., Filimonov A.L. Mohnataja vika pomozhet // Territorija Agro. 2015. № 6. S. 22-24.

5. Rep'ev S.I., Stankeevich A.K., Leonkene L.V. Kul'turnaja flora. T. 4. Ch. 2. Vika. SPb: Izd-vo VIR, 1999. $492 \mathrm{~s}$.
6. Koz'mina N. Biologicheskie osnovy hranenija semjan // Zernobobovye kul'tury. 1963. № 1. S. 28-30.

7. Parahin N.V., Zolotarev V.N., Lahanov A.P. i dr. Vika mohnataja (Vicia villosa Roth.) v kormoproizvodstve Rossii. Orel: Izd-vo OrelGAU, 2010. $508 \mathrm{~s}$.

8. Lukina E.A., Fedotov V.A., Kadyrov S.V. i dr. Semenovedenie i semennoj kontorl': uchebnik. Voronezh: Izdat-Chernozem'e, 2019. $332 \mathrm{~s}$.

9. Korenev G.V., Safonov V.E. Biologicheskie periody vo vremja semjaobrazovanija i sozrevanija goroha // Sel'skohozjajstvennaja biologija. 1982. T. 7, № 5. S. 661-665.

10. Zolotarev V.N., Novoselov Ju.K., Rudoman V.V. i dr. Rekomendacii po vozdelyvaniju i ispol'zovaniju viki mohnatoj (ozimoj) na korm i semena. M., 2007. $45 \mathrm{~s}$. 